\title{
Assessing the Potential Use of Solar Energy Source in Urban Areas Located in Natural Protected Sites
}

\author{
Fabrizio Cumo ${ }^{1}$, Davide Astiaso Garcia ${ }^{2 *}$, Franco Gugliermetti ${ }^{2}$ \\ ${ }^{1}$ Interdisciplinary Centre for Housing, Heritage and Environment (CITERA), Interdisciplinary Centre for Housing, Heritage and En- \\ vironment, Sapienza University, Rome, Italy; ${ }^{2}$ Department of Astronautical, Electrical and Energy Engineering, Sapienza University, \\ Rome, Italy. \\ Email: "davide.astiasogarcia@uniroma1.it
}

Received January $20^{\text {th }}, 2013$; revised February $19^{\text {th }}, 2013$; accepted February $28^{\text {th }}, 2013$

\begin{abstract}
The main aim of this paper is to present an easy to use methodology for assessing the potential amount of electricity or thermal energy production in urban areas located in natural protected sites. The methodology is based on two different steps: a territorial analysis for the evaluation of solar radiation and usable surfaces for photovoltaic or solar thermal plant, and a plant analysis for highlighting those photovoltaic and solar thermal technologies which installation will not generate significant impacts in areas characterized by high environmental and landscaping value. The methodology was successfully applied in two case studies inside two different Italian natural protected areas. The obtained results were provided to local administrations and communities as a useful tool for sustainable energy planning.
\end{abstract}

Keywords: Potential Electricity and Thermal Energy Production from Solar Source; Sustainable Energy Planning; Sustainable Energy Balance

\section{Introduction}

Urban areas, representing the most energy consuming systems [1,2], have been identified as the focal point for apply the sustainable energy targets set by major international agreements [3] and European policies, such as Horizon 2020 (the EU Framework Programme for Research and Innovation) [4], the Strategic Energy Technology Plan (SET Plan), the Smart Cities and CommunitiesEuropean innovation partnership, and the Covenant of Mayors, which are nowadays the most relevant European initiatives supporting the principles of smart cities.

Sustainable energy management within urban agglomerates is unanimously considered one of the crucial elements for achieving a continuous improvement of energy efficiency during the following years. Moreover, according to the last European directives, new targets have been defined for increasing the percentage of energy production from renewable energy sources, trying to approach the zero-carbon goal.

On the other hand, each renewable energy sources has its own constraints and potential impacts, which in many cases limit or reduce its application in urban areas or in the middle of a natural protected area, characterized by high interrelation of human and natural factors.

Consequentially, urban areas inside protected sites can

${ }^{*}$ Corresponding author. be considered as places where the use of renewable energy sources is at the same time advised and difficult to achieve.

In the light of these short considerations, this paper describes a methodology for the assessment of potential solar energy contribution, in order to optimize sustainable energy balance of urban areas in protected sites.

The research work briefly described in this paper come from SoURCE "Sustainable Urban Cells" Bilateral Project of the Executive Programme on Scientific and Technological Cooperation between the Republic of Italy and the Kingdom of Sweden for the years 2010-2013.

SoURCE project is carried out by CITERA (Centro Interdisciplinare Territorio Edilizia Restauro AmbienteInterdisciplinary Centre for Housing, Heritage and Environment), Sapienza University, jointly with the Royal Institute of Technology of Stockholm (School of Architecture and Built Environment, Department of Urban Planning \& Environment).

In particular, among the various topics covered by SoURCE project, this paper highlights the results obtained in the field of solar energy use in urban areas.

Therefore, in order to optimize the energy balance of urban areas, the output of this paper should be considered together with the other topics and methodologies elaborated during the project, regarding above all the reduction of energy consumptions using innovative technologies 
integrated into the built form as well as the assessment of the potential use of other renewable energy sources [5].

\section{Methods}

This paragraph aims to describe an easy to use methodology for assessing solar energy amount of urban areas in natural protected sites, highlighting those strategies able to minimize environmental and landscaping impacts on the surrounding zone.

The methodology foresees that each data gathered according with the methods described in the following subparagraphs, must be recorded in a GIS (Geographic Information index) software for the elaboration of a local database, in order to collect the obtained results in a database containing queried digital maps.

\subsection{Territorial Analysis}

In order to assess the potential use of solar energy source, the first step was to evaluate solar radiation data of the analyzed area, considering solar radiation on the horizontal plan $\left(\mathrm{kWh} / \mathrm{m}^{2}\right)$. This first energy amount does not depend on the human interventions realized in the area (e.g. buildings, facilities), and corresponds to its maximum potentially exploitable solar energy source on the base of the particular climatic and geographical conditions of that zone.

The second step involves a detailed territorial analysis for the identification of all the surfaces where it will be possible to install photovoltaic plants, considering preferentially the one integrated in the top of the buildings, gathering for each roof the approximate angle of slope and the cardinal point where it is facing. In addition, the usable surface of each roof is calculated using GIS software and satellite photographs.

This calculation must not include surfaces on the top of the buildings under a particular constraint or condition which makes unfeasible the installation of any photovoltaic cell or thermal plant, such as roofs of churches or other historical buildings.

Moreover, should be considered any surface on the ground where it will be possible to install a photovoltaic plant, discarding all the areas shaded or subjected to landscaping or environmental constraints.

Is it now possible to quantify the usable surface for a possible installation of thermal or photovoltaic plants of any analyzed area.

This usable surface is usually under the $1 \%$ of the whole analyzed area in sites with high environmental or landscaping value such as National or Regional Parks.

\subsection{Plant Types Choice}

Starting from these two data obtained from the territorial analysis (solar radiation and $\mathrm{m}^{2}$ of usable surface for so- lar plants), it will be possible to evaluate the potential amount of electricity or thermal energy production on the analyzed area using photovoltaic or solar thermal plants.

Obviously this final electricity or thermal energy amount will change according with the selected photovoltaic or thermal plant technologies.

On the other hand, as mentioned in the introduction, the plant choice should be pondered considering also the potential impact which a photovoltaic and a thermal plant could generate in terms of landscaping or environmental alterations. Therefore, answering a specific request of the Italian Ministry for the Environment Land and Sea Protection for increasing energy sustainability of urban areas inside natural protected sites, DIAEE Department of Sapienza University elaborated an ad hoc methodology to quantify the environmental impacts of any different plant typologies, in order to provide the Ministry with clear guidelines for developing innovative methods and strategies to bring energy sustainability and environmental quality into protected areas.

Consequentially DIAEE drew up a technical data sheet for each photovoltaic and solar thermal technology, as well as for other renewable energy sources, in order to evaluate, by means of special equations and matrices [6], the applicability of each technology in natural protected area.

Figure 1 shows as example the technical data sheet for a photovoltaic plant grid connected with amorphous silicon modules of low/medium power.

At this step, considering the average data came out from the analysis of all the acceptable photovoltaic and solar thermal technologies, is it easily possible to assess the potential electricity or thermal energy production in any analyzed area [7].

In particolar, the potential electricity or thermal energy production of an analyzed area $(\mathrm{kWh} /$ year) is obtained multiplying the usable surface for plants $\left(\mathrm{m}^{2}\right)$ for the average photovoltaic or thermal energy productivity in the same area $\left(\mathrm{kWh} / \mathrm{m}^{2}\right.$ year), that obviously depends on the solar radiation value of the zone.

Before this last step, we need to choose which percentage of usable surface we would devote to photovoltaic plants and which percentage we would devote to solar thermal plants.

This choice could be made taking into account the availability of other renewable energy sources in the sur rounding area, such as biomasses (thermal energy) or significant wind regime for micro wind energy plants (electricity).

This because the overall objective is to achieve a complete energy autonomy of small cities inside natural protected area, using renewable energy sources, smart grids as well as strategies and technologies for minimizing energy consumptions. 


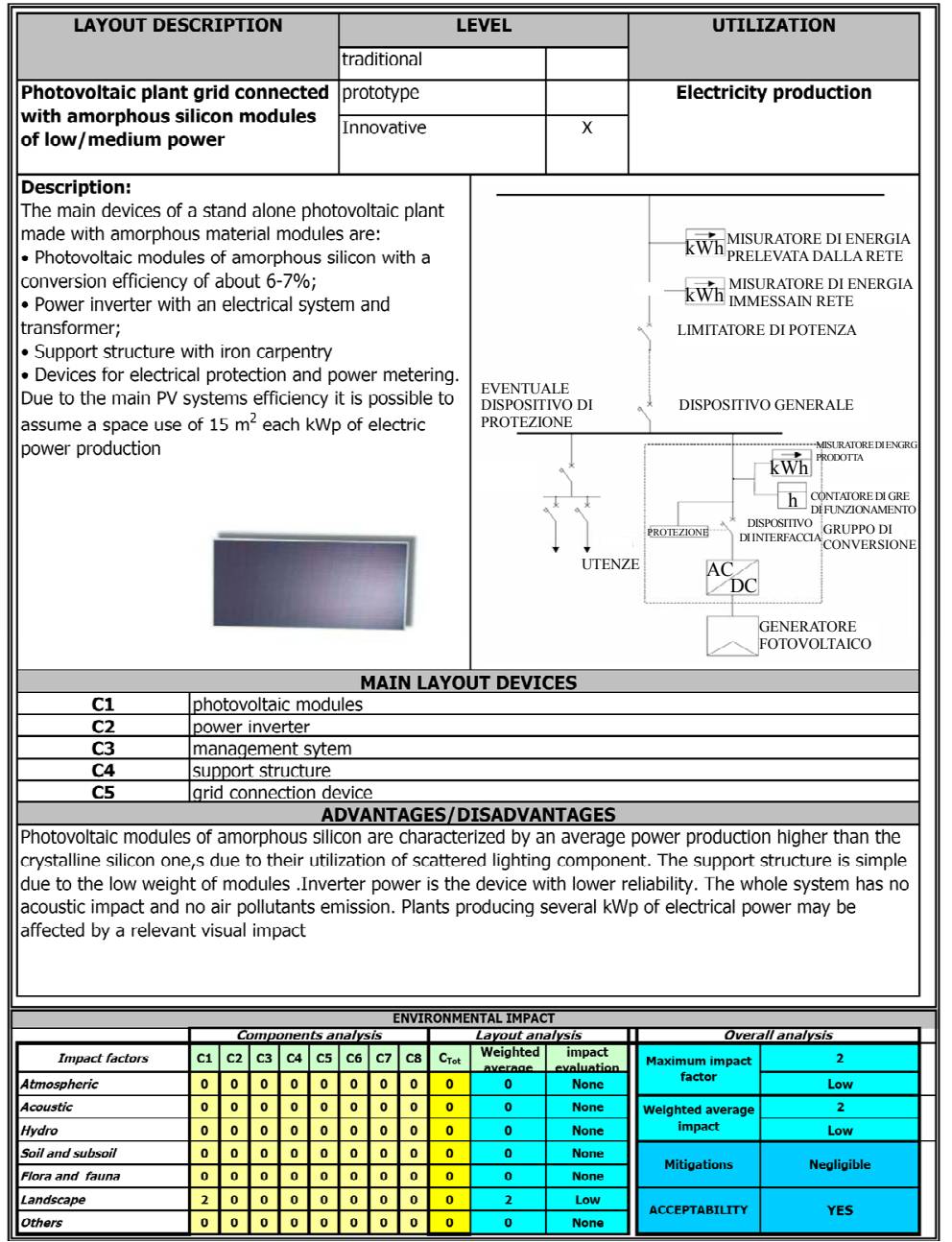

Figure 1. Technical data sheet for a photovoltaic plant grid connected with amorphous silicon modules of low/medium power.

\section{Results}

The methodology described in the above paragraph has been applied in two pilot Italian urban areas (Trevignano Romano and Sabaudia) in order to test its real feasibility.

During these case studies, the analyzed urban areas have been reshaped using SoURCE approach [8], trough the identification of a minimum core of the larger city's model, conventionally called "urban cell".

Moreover, it was decided to assess a final sustainable energy balance between energy production from solar source and energy consumptions. Therefore the electricity and heating expenditures of these areas were assessed, and were consequentially identified some interventions and technologies for the reduction of these consumptions, such as the replace of the casing of windows and energy retrofit of HVAC (Heating, Ventilation and Air Conditioning).

Figures $\mathbf{2}$ and $\mathbf{3}$ show respectively a spatial representation of thermal and electric consumption data collected in a urban cell of Trevignano Romano.

\subsection{The Case Study of Trevignano Romano in Bracciano-Martignano Regional Park}

The urban area of Trevignano Romano, inside the Regional Park of Bracciano-Martignano, was subdivided into four urban cells where the above mention methodology was applied for the assessment of potential solar energy use.

Moreover, some practical solutions and strategies able to influence the environmental performance of building were pinpointed starting from an analysis of service building and facilities [9].

Table 1 summarize the usable surface for solar energy plants in the four urban cells of Trevignano Romano, Table 2 presents the potential electricity using these surfaces only for photovoltaic plants, and Table 3 shows the resulting energy balance.

\subsection{The Case Study of Sabaudia in Circeo National Park}

The results obtained in the case study of Sabaudia shows 


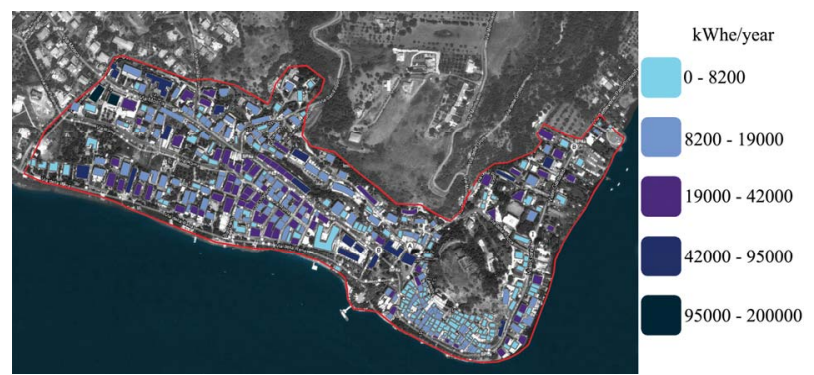

Figure 2. Electric consumptions estimation in an urban cell of Trevignano Romano.

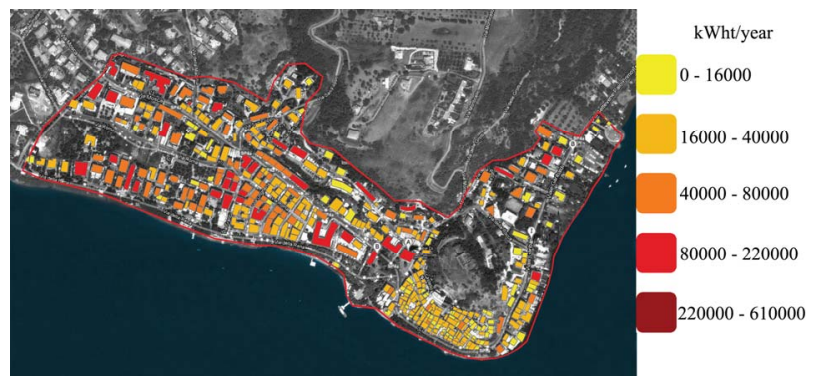

Figure 3. Thermal consumptions estimation in an urban cell of Trevignano Romano.

Table 1. Usable surface for solar energy plants in the four urban cells of Trevignano Romano.

\begin{tabular}{cccccc}
\hline $\begin{array}{c}\text { Urban } \\
\text { Cells }\end{array}$ & $\begin{array}{c}\text { South } \\
\text { facing } \\
\left(\mathrm{m}^{2}\right)\end{array}$ & $\begin{array}{c}\text { South-East } \\
\text { facing }\left(\mathrm{m}^{2}\right)\end{array}$ & $\begin{array}{c}\text { South-West } \\
\text { facing }\left(\mathrm{m}^{2}\right)\end{array}$ & $\begin{array}{c}\text { East } \\
\text { facing } \\
\left(\mathrm{m}^{2}\right)\end{array}$ & $\begin{array}{c}\text { West } \\
\text { facing } \\
\left(\mathrm{m}^{2}\right)\end{array}$ \\
\hline 1 & 4120 & 2984 & 2662 & 2160 & 2294 \\
2 & 5254 & 3173 & 9318 & 2583 & 2622 \\
3 & 2101 & 4147 & 9248 & 2866 & 2758 \\
4 & 0 & 0 & 0 & 0 & 0 \\
Total & 11,475 & 10,304 & 21,229 & 7608 & 7674 \\
\hline
\end{tabular}

Table 2. Potential electricity produced by photovoltaic plants in the four urban cells of Trevignano Romano.

\begin{tabular}{cccccc}
\hline \multicolumn{6}{c}{ Potential electricity produced by photovoltaic plants (kWh/year) } \\
\hline $\begin{array}{c}\text { Urban } \\
\text { Cells }\end{array}$ & $\begin{array}{c}\text { South } \\
\text { facing }\end{array}$ & $\begin{array}{c}\text { South-East } \\
\text { facing }\end{array}$ & $\begin{array}{c}\text { South-West } \\
\text { facing }\end{array}$ & $\begin{array}{c}\text { East } \\
\text { facing }\end{array}$ & $\begin{array}{c}\text { West } \\
\text { facing }\end{array}$ \\
\hline 1 & 529,845 & 364,000 & 322,949 & 224,611 & 236,299 \\
2 & 675,624 & 387,146 & $1,130,331$ & 268,581 & 270,067 \\
3 & 270,177 & 505,932 & $1,121,801$ & 298,086 & 284,048 \\
4 & 0 & 0 & 0 & 0 & 0 \\
Total & $1,475,645$ & $1,257,078$ & $2,575,081$ & 791,278 & 790,414 \\
\hline
\end{tabular}

that this territory is suitable for four ground photovoltaic systems of great power.

Therefore, it was hypothesized only $1 \mathrm{~kW}$ of photovoltaic in each useful roof of residential building. On the other hand, it was hypothesized a $4.2 \mathrm{~m}^{2}$ solar thermal system on each roof of the villas.

Table 4 shows the usable surfaces devoted to photovoltaic and solar thermal plants in the ten urban cells of Sabaudia, while Table 5 represents their final energy balance.

\section{Conclusions}

These results could be integrated with similar analysis for other typologies of renewable energy source. Consequentially it is possible to assess an optimized energy balance for a selected urban area, evaluating the potential reduction of energy expenditures and $\mathrm{CO}_{2}$ emissions. Lastly, the obtained amounts of electricity and thermal energy production from solar source in each analyzed area represent useful results to disseminate to local administrations for helping them in the planning of energy management in their territories.

Table 3. Energy balance in the four urban cells of Trevignano Romano.

\begin{tabular}{ccccccccc}
\hline & $\begin{array}{c}\text { Present } \\
\text { consumptions }\end{array}$ & \multicolumn{2}{c}{$\begin{array}{c}\text { Reduced } \\
\text { consumptions }\end{array}$} & \multicolumn{2}{c}{$\begin{array}{c}\text { Solar } \\
\text { energy }^{\mathrm{a}}\end{array}$} & \multicolumn{2}{c}{$\begin{array}{c}\text { Energy } \\
\text { Balance }^{\mathrm{a}}\end{array}$} \\
\hline $\begin{array}{c}\text { Urban } \\
\text { Cells }\end{array}$ & $\mathrm{T}^{\mathrm{b}}$ & $\mathrm{E}^{\mathrm{c}}$ & $\mathrm{T}^{\mathrm{b}}$ & $\mathrm{E}^{\mathrm{c}}$ & $\mathrm{T}^{\mathrm{b}}$ & $\mathrm{E}^{\mathrm{c}}$ & $\mathrm{T}^{\mathrm{b}}$ & $\mathrm{E}^{\mathrm{c}}$ \\
\hline 1 & $-13,685$ & -6000 & -9200 & -5600 & 2806 & 0 & -6394 & -5600 \\
2 & -3680 & -2000 & -2875 & -1700 & 853 & 1677 & -2022 & -23 \\
3 & $-10,350$ & -4200 & -7475 & -3600 & 0 & 2731 & -7475 & -869 \\
4 & -7130 & -3200 & -5405 & -3000 & 0 & 2480 & -5405 & -520 \\
Total & $-34,845$ & $-15,400$ & $-24,955$ & $-13,900$ & 3659 & 6888 & $-21,296$ & -7012 \\
\hline
\end{tabular}

${ }^{\mathrm{a}} \mathrm{MWh} /$ year. ${ }^{\mathrm{b}} \mathrm{T}$ : Thermal energy. ${ }^{\mathrm{c}} \mathrm{E}$ : Electricity.

Table 4. usable surfaces devoted to photovoltaic and solar thermal plants in the ten urban cells of Sabaudia.

\begin{tabular}{ccc}
\hline $\begin{array}{c}\text { Urban } \\
\text { Cells }\end{array}$ & $\begin{array}{c}\text { Surface devoted to PV } \\
\text { plants }\left(\mathrm{m}^{2}\right)\end{array}$ & $\begin{array}{c}\text { Surface devoted to Solar } \\
\text { thermal plant }\left(\mathrm{m}^{2}\right)\end{array}$ \\
\hline 1 & 3460 & 8 \\
2 & 2110 & 260 \\
3 & 4250 & 1624 \\
4 & 7330 & 2692 \\
5 & 2360 & 944 \\
6 & 10,150 & 2316 \\
7 & 8820 & 3508 \\
8 & 6270 & 2508 \\
9 & 7690 & 2588 \\
10 & 3520 & 1408 \\
Total & 55,960 & 17,856 \\
\hline
\end{tabular}


Table 5. Energy balance in the ten urban cells of Sabaudia.

\begin{tabular}{|c|c|c|c|c|c|c|c|c|}
\hline \multirow[b]{2}{*}{ Urban Cells } & \multicolumn{2}{|c|}{ Present consumptions ${ }^{\mathrm{a}}$} & \multicolumn{2}{|c|}{ Reduced consumptions $^{\mathrm{a}}$} & \multicolumn{2}{|c|}{ Solar energy ${ }^{\mathrm{a}}$} & \multicolumn{2}{|c|}{ Energy Balance $^{\mathrm{a}}$} \\
\hline & $\mathrm{T}^{\mathrm{b}}$ & $\mathrm{E}^{\mathrm{c}}$ & $\mathrm{T}^{\mathrm{b}}$ & $\mathrm{E}^{\mathrm{c}}$ & $\mathrm{T}^{\mathrm{b}}$ & $E^{c}$ & $\mathrm{~T}^{\mathrm{b}}$ & $E^{c}$ \\
\hline 1 & $-15,021$ & $-10,216$ & $-10,513$ & -9092 & 4 & 380 & $-10,509$ & -8712 \\
\hline 2 & -9006 & -5152 & -6575 & -4585 & 130 & 232 & -6445 & -4353 \\
\hline 3 & $-11,244$ & -5561 & -8433 & -4949 & 812 & 467 & -7621 & -4482 \\
\hline 4 & $-24,077$ & $-16,835$ & $-18,057$ & $-14,983$ & 1346 & 806 & $-16,711$ & $-14,177$ \\
\hline 5 & -5812 & -3147 & -4476 & -2800 & 472 & 259 & -4004 & -2541 \\
\hline 6 & -6318 & -2484 & -4675 & -2211 & 1158 & 1286 & -3517 & -925 \\
\hline 7 & $-21,175$ & -9180 & $-15,458$ & -8170 & 1754 & 970 & $-13,704$ & -7200 \\
\hline 8 & $-14,165$ & -6893 & $-11,331$ & -6135 & 1254 & 689 & $-10,077$ & -5446 \\
\hline 9 & $-17,801$ & $-10,201$ & $-13,707$ & -9079 & 1294 & 1736 & $-12,413$ & -7343 \\
\hline 10 & -9653 & -3835 & -6950 & -3413 & 704 & 387 & -6246 & -3026 \\
\hline Total & $-134,272$ & $-73,504$ & $-100,175$ & $-65,417$ & 8928 & 7212 & $-91,247$ & $-58,205$ \\
\hline
\end{tabular}

${ }^{\mathrm{a}} \mathrm{MWh} /$ year. ${ }^{\mathrm{b}} \mathrm{T}$ : Thermal energy. ${ }^{\mathrm{c}} \mathrm{E}$ : Electricity.

This approach was successfully realized with Trevignano Romano Municipalities during and after the elaboration of the case study, providing decision makers and local assessors with the elaborated GIS database of their jurisdiction area.

\section{Acknowledgements}

The authors wish to thanks all the Italian and Swedish researchers who have actively worked on SoURCE project.

In particular, we wish to thanks the engineer Angelo Albo, and the architects Annalisa Scaini and Sabrina Vassallo for their essential work for the elaboration of the case studies of Trevignano Romano and Sabaudia.

Special thanks also to architect Laura Calcagnini for her precious contribute in the methodology elaboration for the assessment of solar potential Energy.

\section{REFERENCES}

[1] World Bank Staff, "Sustainable Land Management: Challenges, Opportunities, and Trade-Offs," The World Bank, Washington DC, 2006.

[2] International Energy Agency, "Promoting Energy Efficiency Investments. Case Studies in the Residential Sector," OECD/IEA and AFD, Paris, 2008.

[3] B. Metz, O. Davidson, P. Bosch, R. Dave and L. Meyer, "Climate Change 2007. Mitigation," Cambridge Univer- sity Press, Cambridge, 2007.

[4] European Commission, "Horizon 2020-The Framework Programme for Research and Innovation-Communication from the Commission COM (2011)," EC, Brussels, 2011.

[5] F. Cumo, D. Astiaso Garcia, L. Calcagnini, F. Rosa and A. S. Sferra, "Urban Policies and Sustainable Energy Management," Sustainable Cities and Society, Vol. 4, No. 1, 2012, pp. 29-34.

http://www.sciencedirect.com/science/article/pii/S221067 0712000182

[6] F. Gugliermetti, F. Rosa and A. Violante, "Metodologia di Valutazione di Impatto Ambientale: Il Caso Studio Dei Sistemi Energetici a Biomassa in Aree Naturali Protette," Proceedings of the 63rd ATI (Associazione Termotecnica Italiana) National Congress, Palermo, 22-26 September 2008, pp. 123-130.

[7] L. Stefanutti, "Impianti per Gli Edifici Sostenibili. Guida ASHRAE Alla Progettazione, Costruzione e Gestione," Tecniche Nuove Editore, Milano, 2009.

[8] F. Cumo, "SoURCE. Towards Smart City," Ugo Quintily Spa, Rome, 2012.

[9] D. Astiaso Garcia, F. Cumo, V. Sforzini and A. Albo, "Eco Friendly Service Buildings and Facilities for Sustainable Tourism and Environmental Awareness in Protected Areas," WIT Transactions on Ecology and the Environment, Vol. 161, WIT Press, Southampton, pp. 323330. doi:10.2495/ST120261 